\title{
O Leoncjuszu i jego zmaganiach o cesarski tron w latach 484-488. Raz jeszcze*
}

Abstract

\section{On Leontius and his struggles for the imperial throne in the years of 484-488. Once again}

\begin{abstract}
This article discusses the usurper Leontius, who opposed the Emperor Zeno in 484 . He was most likely born in a family belonging to the circles of provincial aristocracy, which enabled him to receive a good education. As for his ethnicity, contrary to a rather popular scholarly opinion that he was from Isauria, he might just as well have come from Syria (as Theophanes points out directly). Regarding his position as magister militum per Thracias, it seems that he could have held it in the years 478-482 (there is no certainty that he exercised this function in 484). He probably had known Illus before $481 / 482$ and together, they set off to the East, when Illus was assuming the post of magister militum. Leontius remained at his side until 484, when an open conflict with Zeno broke out. Leontius was proclaimed the emperor because Illus did not want to become one. It seems that the latter valued Leontius and trusted him.

After a moment of triumph on the day of imperial coronation (July 19, 484), only two months later, after the defeat of the forces commanded by Illus in the battle with the imperial forces, Leontius had to take refuge in the fortress of Papyrion, in which he spent about four years, awaiting his demise. He was killed at the hands of imperial soldiers in 488.
\end{abstract}

Keywords: Leontius, Illus, emperor Zeno (475-491), usurpations

* Tekst powstał w ramach projektu sfinansowanego ze środków Narodowego Centrum Nauki, przyznanych na podstawie decyzji nr DEC-2018/31/B/HS3/ 03038 („Wschodniorzymskie elity wojskowe od Teodozjusza II do Anastazjusza I [408-518]. Studium społeczno-polityczne”). 
STRESZCZENIE

\begin{abstract}
A rtykuł poświęcony jest uzurpatorowi Leoncjuszowi, który w 484 r. wystapił A przeciw cesarzowi Zenonowi. Urodził się on zapewne w rodzinie należacej do kręgów prowincjonalnej arystokracji, co umożliwiło mu odebranie dobrego wykształcenia. Co do pochodzenia etnicznego, to wbrew dość powszechnej w nauce opinii, że pochodził z Izaurii, trzeba wskazać, że równie dobrze można uznać, że wywodził się z Syrii (o czym bezpośrednio mówi Teofanes). Co do pełnienia przez niego stanowiska magister militum per Thracias, to wydaje się, że mógł je sprawować w latach 478-482 (nie ma pewności, że był nim w 484 r.). Najpewniej znał się w otoczeniu Illusa jeszcze przed 481/482 r. i z nim wyruszył na Wschód, gdy ten przejmował stanowisko magister militum i pozostał u jego boku do 484 r., kiedy wybuchł otwarty konflikt z Zenonem. Leoncjusz został proklamowany cesarzem, ponieważ Illus nie chciał nim zostać. Wydaje się, że ten ostatni cenił Leoncjusza i darzył go zaufaniem.

Po chwili triumfu w dniu cesarskiej koronacji (19 lipca 484 r.) Leoncjusz raptem w dwa miesiące później - po klęsce sił dowodzonych przez Illusa w bitwie z siłami cesarskimi - musiał schronić się w twierdzy Papyrion, w której spędził około czterech lat, czekając na śmierć. Ta ostatnia spotkała go $z$ rąk cesarskich żołnierzy w $488 \mathrm{r}$.
\end{abstract}

Słowa kluczowe: Leoncjusz, Illus, cesarz Zenon (475-491), uzurpacje

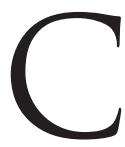

esarz Zenon, z pochodzenia Izauryjczyk, w czasie trwajacych 17 lat rządów, kilkukrotnie musiał mierzyć się z uzurpatorami, którzy chcieli pozbawić go władzy ${ }^{1}$. Jedną

1 Już u początków swoich rządów (szerzej na ich temat por. R. Ko siński, The Emperor Zeno. Religion and Politics, Cracow 2010; P. Craw ford, Roman Emperor Zeno: The Perils of Power Politics in Fifth-century Constantinople, Yorkshire-Philadelphia 2019) w styczniu roku 475 Zenon stanał w obliczu uzurpacji Bazyliskosa, wuja swojej małżonki Ariadny, któremu poparcia udzieliła Weryna, teściowa cesarza, jak również dowódcy wojskowi: Armatus (zapewne siostrzeniec Bazyliskosa), Illus i jego brat Trokundes, Teodoryk Strabon, król Gotów. Zenon musiał opuścić Konstantynopol, do którego powrócił w sierpniu roku 476, usuwając Bazyliskosa $z$ tronu. Na temat kariery uzurpatora i jego losów por. m.in.: E.W. Brooks, The Emperor Zeno and the Isaurians, "English Historical Review” 1893, vol. VIII, s. 216-218; J.R. Martindale, The Prosopography of the Later Roman Empire, vol. II (A.D. 395-527) [dalej: PLRE II], Cambridge 1980, s. 212-214 (Fl. Basiliscus 2); M. Salamon, Basiliscus cum Romanis suis, [w:] Studia Moesiaca, red. L. Mrozewicz, K. Ilski, Poznań 1994, s. 179-196; M.J. Leszka, Empress- Widow Verina's Political Activity during the Reign of Emperor Zeno, [w:] Mélanges d'histoire byzantine offerts à Oktawiusz Jurewicz à l'occasion de son soixante-dixième Anniversaire, ed. W. Ceran, Łódź 1998, s. 128-133; J. Prostko-Prostyński, Basiliskos: Ein in Rom anerkannter Usurpator, „Zeitschrift für Papyrologie und Epigraphik" 2000, Bd. CXXXIII, s. 259-263; K. Feld, Barbarische Bürger. Die Isaurier und das Römische Reich, Berlin 2005, s. 241-260; M.J. Le s z k a, Illus Izau- 
z takich prób, zresztą ostatnia, było wystapienie Illusa, długoletniego współpracownika cesarza, który doprowadził do proklamacji cesarskiej Leoncjusza. Losy tego ostatniego stanowia przedmiot moich rozważań. Mimo że znajdowały się one już w obrębie zainteresowania uczonych, to warto się im przyjrzeć raz jeszcze.

O drodze życiowej Leoncjusza ${ }^{2}$ do czasu, kiedy związał się z Illusem, wiadomo niewiele. Dysponujemy niejasnym wyobrażeniem o jego pochodzeniu. Jan $z$ Antiochii twierdzi, że Leoncjusz wywodził się $z$ Dalisandos ${ }^{3}$. Nie podaje jednak, gdzie ono się znajdowało ani nie informuje o jego etnicznym pochodzeniu. Niektórzy uczeni sądzą, że historyk miał na myśli Dalisandos, leżące w pobliżu Klaudiopola ${ }^{4}$, i buduja na tej podstawie hipotezę o izauryjskim pochodzeniu Leoncjusza ${ }^{5}$. Jan $z$ Antiochii informuje również, że Leoncjusz był niskiego pochodzenia ${ }^{6}$. $Z$ kolej Teofanes w Chronografii najpierw pisze, że Leoncjusz był z pochodzenia Syryjczykiem

ryjczyk wobec uzurpacji Bazyliskosa, „Acta Universitais Lodziensis. Folia Historica" 2005, z. 80, s. 45-49; K. Tw a rd ow s ka, Cesarzowe bizantyńskie 2 pot. Vw. Kobiety i władza, Kraków 2009, s. 109-124; R. Ko siński, op. cit., s. 79-97.

W trzy lata później przeciwko Zenonowi wystąpił Marcjan, jego szwagier, mąż Leoncji, siostry Ariadny. Wystapienie to udało się stłumić m.in. dzięki wsparciu Illusa. Na temat Marcjana i jego wystapienia: W. En s slin, Marcianus 35, [w:] Paulys Realencyclopädie der classischen Altertumswissennschaft [dalej: RE], Bd. XIV, 2, Stuttgart 1956, kol. 1519; PLRE II, s. 717 (Marcianus 17); M.J. Leszka, Bunt Marcjana $w$ Konstantynopolu (479), [w:] $Z$ badań nad wczesnobizantyńskim Konstantynopolem, red. M.J. Leszka, K. Marinow, A. Kompa, Łódź 2011 (= „Acta Universitatis Lodziensis. Folia Historica" 2011, z. 87), s. 215-225; Ch. Be gas s, Die Senatsaristokratie des oströmischen Reiches, ca. 457-518. Prosopographische sozialgeschichtliche Untersuchungen, München 2018, s. 185-186, 293-295.

2 Podstawowe informacje o Leoncjuszu: W. Ens slin, Leontius, [w:] RE, Suppl. Bd. VIII, k. 939-941; PLRE II, s. 670-671 (s.v. Leontius 17); Ch. Begas s, op. cit., s. 175-177. O karierze Leoncjusza do roku 481/482 pisałem szerzej w tekście: On Leontius' Origin and Career up until the Year 481/482, „Piotrkowskie Zeszyty Historyczne" 2020, t. XXI, z. 3, s. 9-18.

${ }^{3}$ Jan z Antiochii, 237.2 (Ioannis Antiocheni Fragmenta quae Supersunt Omnia, rec. S. Mariev, Berolini et Novi Eboraci 2008).

${ }^{4}$ F. Hild, H. Helle nke m per, Kilikien und Isaurien, Teil I, Wien 1990 (Tabula Imperii Byzantini, Bd. 5.1), s. 233-234.

5 E.W. Brooks, op. cit., s. 225, przyp. 101; W. Ens slin, Leontius..., kol. 939; Pogląd o izauryjskim pochodzeniu Leoncjusza utrwalił się w nauce, np. J. Kulakovkij, Istorija Vizantii, t. I, London 1973, s. 372; H. E1ton, Illus and the Imperial Aristocracy under Zeno, „Byzantion” 2000, vol. LXX, s. 399; R. Kosins ki, op. cit. s. 148; A. Ki el-Freytag, Betrachtungen zur Usurpation des Illus und des Leontius (484-488 n. Chr., „Zeitschrift fur Papyrologie und Epigraphik” 2010, Bd. CLXXIV, s. 292.

${ }^{6}$ Jan $z$ Antiochii, 237.2. 
i do tego dobrze wykształconym ${ }^{7}$, a w innym passusie dodaje, że rodzinnym miastem Leoncjusza było Chalkis ${ }^{8}$. Miasto to znajduje się na terenie Syrii, czego już jednak Teofanes nie wzmiankuje. Dwukrotne wskazanie przez Teofanesa (oczywiście za wykorzystanym w tym fragmencie wcześniejszym źródłem) na Syrię jako miejsce narodzin Leoncjusza wydaje się ważkim argumentem na rzecz tezy o syryjskim pochodzeniu mojego bohatera. Należy również zwrócić uwagę, że imię Leoncjusz było dość popularne na terenie Syrii ${ }^{9}$, co oczywiście nie musi być szczególnie istotną wskazówka.

Co do argumentów przeciw izauryjskiemu pochodzeniu Leoncjusza, to w mocy pozostaja zastrzeżenia Glanville'a Downeya ${ }^{10}$, że nie można mieć pewności, że Janowi z Antiochii chodziło o Dalisandos w Izaurii, a nie o inną miejscowość o tej nazwie, a wiemy, że takie istniały i nie można wykluczyć, że jedna $z$ nich leżała na terenie Syrii. Wywód Downeya służy wskazaniu na możliwość, że przekaz Jana $z$ Antiochii nie jest sprzeczny $z$ przekazem Teofanesa. Jeśliby nawet tak było, to wtedy powstaje problem, dlaczego Teofanes pisze wyraźnie, że miastem rodzinnym Leoncjusza było Chalkis. A skoro akceptujemy informację Teofanesa o syryjskim pochodzeniu Leoncjusza, to dlaczego nie przyjąć również tego, że miejsce jego narodzin to Chalkis, i uznać, że Jan $z$ Antiochii po prostu się pomylił. Nie ma powodu zakładać apriorycznie, że Jan $z$ Antiochii dysponował bardziej wiarygodnymi źródłami niż Teofanes. Przeciw izauryjskiemu pochodzeniu Leoncjusza przemawia także przekaz Pseudo-Jozuego Stylity, w którym mowa jest o tym, że Illus nie ogłosił siebie cesarzem m.in. $z$ powodu swojego izauryjskiego pochodzenia ${ }^{11}$. Świadczy to wyraźnie o tym, że Leoncjusz Izauryjczykiem, przynajmniej takim jak Illus, nie był.

W słowiańskim tłumaczeniu Chronografii Jana Malalasa pojawia się informacja, że Leoncjusz był $z$ pochodzenia Trakiem. Uznaje się ją powszechnie za błąd ${ }^{12}$.

7 Teofanes (Theophanes, Chronographia, rec. C. de Boor, Lipsiae 1883), AM 5972, s. 128.

8 Teofanes, AM 5976, s. 129.

${ }^{9}$ Ch. Begas s, op. cit., s. 176.

10 G. Downey, A History of Antioch in Syria from Seleucus to the Arab Conquest, Princeton-New Jersey 1961, s. 494, przyp. 95.

${ }^{11}$ Pseudo-Jozue Stylita (The Chronicle of Pseudo-Joshua the Stylite, trans1., notes and introduction F.R. Trombley, J.W. Watt, Liverpool 2000), 14.

${ }_{12}$ V.M. Is trin, Hronika Ioanna Malaly $v$ slavjanskom perevode, Moskva 1994 [dalej: Jan Malalas (słow.)], s. 340. Błąd ten wynikać ma z tego, że Leoncjusz 
Z powyższych rozważań wynika, że w kwestii pochodzenia Leoncjusza jednoznacznie wypowiada się jedynie Teofanes, który mówi o nim jako Syryjczyku i wskazuje jako miejsce jego narodzin - Chalkis. Koncepcja izauryjskiego pochodzenia Leoncjusza oparta jest tylko na nazwie Dalisandos, podanej przez Jana $z$ Antiochii, a która współcześnie uczeni wiążą $z$ terenami izauryjskimi ${ }^{13}$.

Dysponujemy jeszcze jednym szczegółem dotyczącym rodziny Leoncjusza. Jan Malalas podaje imię matki Leoncjusza - Paulina ${ }^{14}$, nie wspomina natomiast imienia ojca. Słusznie zauważa Maciej Salamon $^{15}$, że podanie imienia matki Leoncjusza może świadczyć, że pochodziła $z$ jakiegoś znaczącego rodu. Współgrałoby to $z$ informacja Teofanesa o dobrym wykształceniu bohatera artykułu oraz przekazem słowiańskiego przekładu Malalasa ${ }^{16}$.

O karierze Leoncjusza do czasu jego cesarskiej proklamacji wiemy tyle, że miała ona charakter wojskowy, a jej ukoronowaniem było, jak się wydaje, stanowisko magister militum per Thra$\operatorname{cias}^{17}$. Nie wiemy, kiedy Leoncjusz je otrzymał. Wydaje się, że w grę może wchodzić schyłek lat siedemdziesiątych i początek osiem-

był magister militum per Thracias (por. np. PLRE II, s. 670). Jeśli tak jest w rzeczywistości, to trzeba zwrócić uwage na to, że słowiański tłumacz dzieła Malalasa dysponował pełniejsza wersja dzieła Jana, ponieważ w znanej nam obecnie greckiej wersji informacji o sprawowaniu tego stanowiska przez Leoncjusza nie ma. Na temat tradycji rękopiśmiennej Chronografii Jana Malalsa: P. Janiszewski, Historiografia późnego antyku (koniec III - połowa VII w.), [w:] Vademecum historyka starożytnej Grecji i Rzymu, t. III (Źródłoznawstwo czasów późnego antyku), red. E. Wipszycka, Warszawa 1999, s. 173-174.

${ }^{13}$ Nie można całkowicie wykluczyć koncepcji starającej się pogodzić dwie źródłowe tradycje dotyczące pochodzenia Leoncjusza, według której jego rodzina wywodziła się $z$ Syrii, skąd przeniosła się do Izaurii. Jest to jednak jedynie domysł, który nie ma podstaw źródłowych.

${ }^{14} \mathrm{Jan}$ Malalas (Ioannis Malalae chronographia, rec. J. Thurn, Berolini et Novi Eboraci 2000), XV, 13. Żadne inne źródło nie wspomina Pauliny jako matki Leoncjusza, mimo to uznaje się tę informację za prawdziwą. W materiale epigraficznym, pochodzącym $z \mathrm{~V}$ w. $z$ terenów Izaurii, znaleziono imię Pauliny, żony Zenona Starszego. Próba jej łączenia, a tym samym i Zenona, z Leoncjuszem wydaje się nazbyt karkołomna. Por. Ch. Be gas s, op. cit., s. 176.

15 M. Salamon, Pamprepiusz z Panopolis - pisarz, profesor, polityk, obrońca pogaństwa $w$ Cesarstwie Wschodnim, [w:] Studia classica et byzantina. Alexandro Krawczuk oblata, red. M. Salamon, Z.J. Kapera, Kraków 1996, s. 185.

16 Teofanes, AM 5972, s. 128; Jan Malalas (słow.), s. 341.

17 Teofanes, AM 5972, s. 128. Watpliwości E.W. Brooks a (op. cit., s. 226) co do pełnienia przez Leoncjusza tego stanowiska sa słabo uzasadnione. Autor ten twierdzi, że Teofanes się pomylił, bo takiej informacji nie ma w jego podstawowym dla tej kwestii źródle, czyli Chronografii Jana Malalasa. Takiej pewności mieć nie możemy - por. na ten temat przyp. 13. 
dziesiątych. $Z$ okresu poprzedzającego wskazany czas znany jest $z$ imienia magister militum per Thracias - Herakliusz, który pełnił to stanowisko w 474 r. Został zabity przez Gotów ${ }^{18}$. W źródłach wspominany jest jeszcze w zwiąku $z$ wydarzeniami 478 r. jakiś magister militum per Thracias, którego $z$ pewnością nie można utożsamiać $z$ Leoncjuszem ${ }^{19}$. Wynika $z$ tego, że Leoncjusz mógł najwcześniej otrzymać to stanowisko od cesarza Zenona w 478 r. Nie jest oczywiste, że pełnił je w 484 r., jak się dość powszechnie sązi ${ }^{20}$. Teofanes, który jako jedyny podaje informację o pełnieniu przez Leoncjusza naczelnego dowództwa w Tracji, praktycznie w jednym zdaniu zamieszcza wszystko to, co o nim wiedział lub uznał za ważne. Ze zdania tego wynika jedynie tyle, że w jakimś momencie swojego życia był Leoncjusz magister militum per Thracias. Trzeba zauważyć, że informacja o Leoncjuszu u Teofanesa pojawia się nie w kontekście wydarzeń $z$ roku 484, a w związku $z$ opuszczeniem przez Illusa Konstantynopola, co datuje się na 481/482 r. Nie wiemy, kto był bezpośrednim następca Leoncjusza na tym stanowisku. Następny uchwytny źródłowo magister militum per Thracias - Julian znany jest dopiero z początków rządów Anastazjusza $^{21}$.

Wracajac do kwestii kariery Leoncjusza, trzeba odnotować fakt, że został on - zapewne za swoje wojskowe dokonania - obdarowany przez cesarza tytułem patrycjusza oraz konsula (honorowego) ${ }^{22}$. Także w tym przypadku nie wiemy, kiedy to się stało. Gdyby wiązać

18 PLRE II, s. 542 (Heraclius 4). Warto zwrócić uwagę, że bez specjalnych luk znamy magistrów militum per Thracias od $464 \mathrm{r}$.

${ }_{19}$ Malchus (Testimonia, [w:] The Fragmentary Classicising Historians of the Later Roman Empire. Eunapius, Olympiodorus, Priscus and Malchus, ed. R.C. Blockley, vol. II, Liverpool 1983), 15-16. Por. PLRE II, s. 1223 (Anonymus 21).

${ }^{20}$ PLRE II, s. 670; por. uwagi Macieja Salamona - Pamprepiusz..., s. 183, przyp. 95.

${ }^{21}$ PLRE II, s. 639 (Iulianus 15). Julian znany jest jedynie ze wzmianki w Kronice Marcellin a Komes a (The Chronicle of Marcellinus. A Translation and Commentary [with a reproduction of Mommsen' edition of the text] B. Croke, Sydney 1995), a. 493. Autor odnotowuje jego śmierć w walce ze Scytami. Prawdopodobnie pod tym etnonimem kryja się Bułgarzy. Ze wzmianki tej wynika, że Julian pełnił to stanowisko już jakiś czas, ale czy był bezpośrednim następcą Leoncjusza, tego nie da się dowieść.

${ }^{22}$ Teodor Lektor (Theodoros Anagnostes, Kirchengeschichte, Epitome, hrsg. G.C. Hansen, Berlin 1995), 437. Na listach konsulów imienia Leoncjusza nie ma - por. S.R. Bagnall, A. Cameron, R.S. Schwartz, A. Klaas Worp, Consuls of the Later Roman Empire, Atlanta 1987. 
to $z$ pełnieniem stanowiska dowódcy wojsk w Tracji, to trzeba by wskazać na czasy panowania Zenona.

Dramatyczny zwrot w dobrze, jak można sądzić, rozwijającej się karierze Leoncjusza nastąpił w chwili, kiedy został wciagnięty w nabrzmiały konflikt między cesarzem Zenonem a jego wieloletnim współpracownikiem Illusem.

Nie ma potrzeby $\mathrm{w}$ tym miejscu przedstawiać dobrze znanych losów relacji Illusa $z$ Zenonem. Wydaje się natomiast, że na użytek tego tekstu trzeba nieco miejsca poświęcić okolicznościom zerwania współpracy między nimi. Decydująca rola, jaka Illus odegrał w stłumieniu próby uzurpacji Marcjana, który w 479 r. wystąpił przeciw Zenonowi, choć na jakiś czas pozwoliła zachować Illusowi dotychczasowa pozycję $\mathrm{w}$ państwie, to paradoksalnie w ostatecznym rozrachunku doprowadziła do takiej sytuacji, w której dalsza współpraca między nim a Zenonem stała się przynajmniej na jakiś czas niemożliwa. Źródła pozwalają z pozoru określić powody, dla których Illus opuścił Konstantynopol. Wskazuja na konflikt, jaki rozgorzał między nim a cesarzową Ariadna, żoną Zenona, w kwestii uwolnienia cesarzowej Weryny. Illus nie chciał zgodzić się na uwolnienie matki Ariadny, czego następstwem był nieudany zamach na jego życie zorganizowany przez ludzi cesarzowej za wiedza i zgoda Zenona ${ }^{23}$. Te wydarzenia sa powszechnie znane. W ich konsekwencji Illus zdecydował się na opuszczenie Konstantynopola, a uczynił to za zgoda Zenona, który wyznaczył go magister militum per Orientem. Jego siedzibą miała się stać Antiochia. Dlaczego Zenon, pozbywając się Illusa $z$ Konstantynopola, obdarzył go tak strategicznym stanowiskiem i dał swobodę działania? Musiał mieć przecież świadomość, że w razie ostatecznego zerwania Illus może wykorzystać przeciw niemu siły, którymi będzie dysponował jako dowódca armii na Wschodzie.

Skromne wzmianki źródłowe i dalszy rozwój sytuacji pozwala sformułować w tej kwestii następujące wnioski ${ }^{24}$. Po pierwsze, jest

${ }^{23}$ Najpełniejszy opis wydarzeń daje Jan Malalas, XV, 13; Jan z Nikiu (The Chronicle of John, bishop of Nikiu, transl. R.H. Charles, Oxford 1916), 88. 68-74; Te ofanes AM 5972. O wrogości Zenona wobec Illusa por. też Ps eudo-Jozue Stylita, 13; Kandyd Izauryjczyk (Candidus, Fragmenta, [w:] The Fragmentary Classicising Historians of the Later Roman Empire. Eunapius, Olympiodorus, Priscus and Malchus, ed. R.C. Blockley, vol. II, Liverpool 1983), s. 468, 470.

${ }^{24}$ Szerzej na ten temat pisałem w tekście Kilka uwag na temat losów Illusa Izauryjczyka w latach 479-484, „Meander” 2007, R. XL, z. 1-2, s. 103-105. 
oczywiste, że cesarz Zenon po nieudanym zamachu na Illusa nie był gotów do ostatecznej z nim rozprawy. Wydaje się, że wynikało to $z$ układu sił. Illus dysponował, jak można wnioskować $z$ historii stłumienia przez niego wystapienia Marcjana, stosunkowo silnym zapleczem militarnym w stolicy i dlatego Zenon nie chcial ryzykować otwartej konfrontacji, szczególnie że, jak donosi Jan $z$ Antiochii, był zagrożony ze strony Ostrogotów ${ }^{25}$. Obserwując na przestrzeni lat poczynania cesarza wobec pobratymca, można dojść do wniosku, że bez względu na sytuację nie dążył on do jawnego $z$ nim konfliktu. Ukrywał się za poczynaniami innych i wypierał się jakichkolwiek związków $z$ tymi, którzy starali się pozbawić Illusa życia ${ }^{26} . Z$ drugiej strony Illus mimo kolejnych akcji skierowanych przeciw niemu wciąż gotów był na kompromis. Tak rzecz się miała nawet po zamachu zorganizowanym przez Ariadnę. Malalas pisze, że choć Illus nie wierzył w zapewnienia Zenona, że nie maczał on palców w tym przedsięwzięciu, to jednak powstrzymał swój gniew ${ }^{27}$. Ta pojednawcza postawa Illusa dawała Zenonowi nadzieję, że magister officiorum nie zechce w przyszłości przeciw niemu występować. Zgodził się na jego prośbę i pozwolił wyjechać na Wschód, obdarzywszy wysokim stanowiskiem ${ }^{28}$, bo wydawało mu się to dobrym

${ }^{25}$ Jan $z$ Antiochii, 236. Na temat stosunków Zenona $z$ Gotami w tym czasie por. E. De mouge ot, La formation de l'Europe et les invasions barbares, t. II (De l'avènement de Dioclétien [284] à l'occupation germanique de l'Empire romain d'Occident [début du VI e siècle/), Paris 1979, s. 789-790; P.J. H e a th e r, Goths and Romans 332-489, Oxford 1991, s. 303-304; H. Wolfr a m, Historia Gotów, przekł. R. Darda-Staab i in., Warszawa-Gdańsk 2003, s. 313-318; M. Wilczyńs ki, Germanie $w$ służbie zachodniorzymskiej $w V w$. n.e., Oświęcim 2018, s. 423-424.

${ }^{26}$ Źródła stosunkowo często ukazują Zenona jako człowieka słabego i skłonnego do intryg, ale i łagodnego. Na ten temat por. A. La niado, Some Problems in the Sources for the Reign of the Emperor Zeno, „Byzantine and Modern Greek Studies” 1991, vol. XV, s. 147-173; M. Whitby, Evagrius on Patriarchs and Emperors, [w:] The Propaganda of Power. The Role of Panegyric in Late Antiquity, ed. idem, Leiden-Boston-Köln 1998, s. 337-338; L.I. C o n rad, Zeno, the Epileptic Emperor: Historiography and Polemics as Sources of Realia, „Byzantine and Modern Greek Studies" 2000, vol. XXIV, s. 61-81. Por. też K. Ginter, Wizerunek władców bizantyńskich w Historii kościelnej Ewagriusza Scholastyka, Łódź 2018, s. 142-153.

27 Jan Malalas, XV, 13.

28 Teofanes (AM 5972, s. 128) informuje, że Illus otrzymał większe uprawnienia niż te, które normalnie mieli magistri militum Wschodu (prawo do mianowania dowódców wojskowych - duces). Niektórzy uczeni akceptuja ten przekaz (np. E.W. Brooks, op. cit., s. 223; G. Down ey, op. cit., s. 490). Budzi on jednak znaczne wątpliwości - na ten temat por. E.P. Gluša nin, Voennaja znat' rannej Vizantii, Barnaul 1991, s. 152. Autor ten uważa, że być może między Illusem a Zenonem doszło do porozumienia, na mocy którego ten pierwszy zgodził się na 
rozwiązaniem. Nie musiał obawiać się, że urażony i zdesperowany Illus podejmie jakieś działania przeciw niemu, co, gdyby przebywał on w stolicy, mogło być niezwykle niebezpieczne. Wysyłając pobratymca na Wschód, dawał mu co prawda swobodę działania, ale i sam ja zyskiwał, mając także czas na przygotowanie się do ewentualnej konfrontacji lub na wyciszenie zaistniałego konfliktu ${ }^{29}$. Obserwując dalszy rozwój wydarzeń, można dojść do wniosku, że także Illusa zadowalało takie rozwiązanie ${ }^{30}$. Przez około dwa lata bowiem nie podejmował wrogich Zenonowi działań ${ }^{31}$, a jego wystąpienie w 484 r. zostało sprowokowane przez cesarza, który zażądał od niego uwolnienia Longinusa, swego brata, a gdy Illus odmówił, pozbawił go stanowiska i podją represje przeciw jego zwolennikom w Konstantynopolu ${ }^{32}$. To oznaczało ostateczne zerwanie między Zenonem a Illusem. Illus, choć był z pewnościa człowiekiem ambitnym, to zdobycia cesarskiej korony nie miał w swoich planach. Gdyby było inaczej, mógł wybrać lepszy moment, jak choćby stłumienie uzurpacji Marcjana, gdy decydował o losach Zenona. Illus był politykiem elastycznym, gotowym na kompromis i potrafiacym zostawiać sobie furtkę na wypadek, gdyby wypadki nie rozwijały się po jego myśli. Niewystawienie własnej kandydatury pozostawiało mu nadzieję na ewentualne porozumienie $z$ cesarzem, gdyby akcja, która podjał, się nie powiodła. Jego wybór padł na Leoncjusza.

opuszczenie wraz ze swoimi ludźmi stolicy w zamian za zapewnienie mu przez Zenona bezpieczeństwa na Wschodzie.

${ }^{29}$ Warto przypomnieć, że Illus już raz opuścił Konstantynopol - po zamachu na swoje życie zorganizowanym $z$ inspiracji Weryny i przez czas jakiś przebywał w Izaurii. Powrócił do stolicy na prośbę Zenona, który dla potwierdzenia swoich dobrych intencji wydał mu Werynę jako zakładniczkę. Być może w chwili, kiedy Illus w 482 r. wyjechał z Konstantynopola, zarówno on sam, jak i Zenon nie wykluczali jego powrotu do stolicy i unormowania wzajemnych stosunków. O tym, że Zenon próbował później zrealizować taki scenariusz, może świadczyć przekaz Pseudo-Jozuego Stylity, 14.

30 Poza swoboda działania i prestiżowym stanowiskiem dawało mu ono poczucie bezpieczeństwa. Przebywając poza Konstantynopolem, przestał bowiem być narażony na kolejne zamachy. Warto również podkreślić, że wedle przekazów źródłowych to on miał być inspiratorem takiego rozwiązania, można przeto sądzić, że musiało go ono satysfakcjonować.

${ }^{31}$ E.P. Glu šanin, op. cit., s. 153. Niektórzy uczeni uważają jednak, że w tym czasie Illus przygotowywał się do rozprawy z Zenonem - por. np. G. Downey, op. cit., s. 491.

${ }^{32}$ Część źródeł wyraźnie wskazuje na Zenona jako tego, który rozpoczął kroki w kierunku ostatecznej rozprawy z Illusem - Pseudo-Jozue Stylita, 14; Jan z Antiochii, 237.1. 
W tym miejscu trzeba rozpatrzeć okoliczności, w jakich Leoncjusz znalazł się w otoczeniu Illusa. Sa one ukazywane w źródłach w różny sposób. Według najwcześniejszego przekazu, znajdującego się w zaginionym dziele Eustacjusza $z$ Epifanei ${ }^{33}$ - który został wykorzystany przez późniejszych historyków bizantyńskich: Jana Malalasa, Ewagriusza Scholastyka i Teofanesa Wyznawce - Leoncjusz znalazł się w otoczeniu Illusa w chwili, kiedy ten opuścił Konstantynopol i udał się na Wschód, by objąc stanowisko magister militum per Orientem ${ }^{34}$.

Inną wersję wydarzeń przedstawia w swojej Kronice, ukończonej niedługo po 506 r., Pseudo-Jozue Stylita. Według jego przekazu Leoncjusz pojawił się u Illusa dopiero wtedy, gdy ten znajdował się na Wschodzie. Cesarz Zenon miał go wysłać z jakimś oddziałem wojska do Illusa, $z$ zadaniem pojmania go i przywiezienia do Konstantynopola, a w razie oporu - zabicia go. Leoncjusz nie zrealizował misji, dał się przekupić Illusowi i przeszedł do jego obo$z^{35}$. Wersje Pseudo-Jozuego potwierdza Jordanes ${ }^{36}$ i w pewnym stopniu, zdaniem E.W. Brooksa ${ }^{37}$, Liberatus, autor $z$ Afryki ${ }^{38}$, który

${ }^{33}$ Eustacjusz pochodził z Epifanei w Syrii. Był autorem Krótkiej kroniki. Składała się ona $z$ dwóch ksiag. Obejmowała dzieje od początku świata (prawdopodobnie) po rok 503 (zdobycie Amidy przez szacha perskiego Kawada). Nie została ukończona i się nie zachowała. Spod pióra Eustacjusza wyszedł też wyciagg z Dawnych dziejów Izraela Józefa Flawiusza. Historyk zmarł w 503 r. Na jego temat por. m.in.: M. Salamon, Problem upadku Cesarstwa rzymskiego $w$ greckiej historiografii powszechnej początków VI wieku (Zosimos i Eustacjusz z Epifanii), „Historia i Współczesność" 1978, t. III, s. 115-129 (= Problemy schyłku świata antycznego, red. A. Kunisz, Katowice 1978, s. 115-127); P. Alle n, Evagrius Scholasticus the Church Historian, Leuven 1981, s. 7-8; P. Jan is zews ki, op. cit., s. 167-169.

${ }^{34} \mathrm{Jan}$ Malalas, XV, 13 (Illus miał poprosić cesarza, by posłał $\mathrm{z}$ nim Leoncjusza, pod którego opieka miała wrócić do Konstantynopola Weryna, matka Ariadny); Ewagriusz Scholastyk, III, 27: „Illos zaś przybrawszy sobie do towarzystwa Leoncjusza oraz Marsosa, człowieka znamienitego, i Pamprepiusza, udał się na Wschód" (przekł. s. 138); Teofanes AM 5972, s. 128 (Illus wziął ze soba patrycjusza Leoncjusza, Marsusa i senatora Pamprepiusza); por. Jan z Nikiu, 88.76.

${ }^{35}$ Pseudo-Jozue Stylita, 14.

${ }^{36}$ Jordanes, Romana, 352, [w:] Monumenta Germaniae Historica. Auctores antiquissimi, t. V, pars prior, ed. Th. Mommsen, Berolini 1882: contra quem [Illusowi - M.J.L.] Leontius directus....

${ }^{37}$ E.W. Brooks, op. cit., s. 225. Nie można, wbrew zdaniu tego autora, wykluczyć, że Pseudo-Jozue Stylita i Jordanes - który pisał swoją Historię rzymska jakieś 50 lat po tym pierwszym - korzystali $z$ tego samego źródła.

${ }^{38}$ Li b e ratu s, Breviarium cause Nestorianorum et Eutychianorum, 17, [w:] Acta Oecumenicorum Conciliorum, ed. E. Schwartz, t. II, vol. 5, Berolini-Lipsiae 1936. 
jednak myli postacie, wskazując, że to Leoncjusz był buntownikiem, przeciwko któremu wysłany został Illus.

Pozostałe źródła nie wnoszą niczego do sprawy okoliczności pojawienia się Leoncjusza w otoczeniu Illusa. Odnotowruja one Leoncjusza dopiero w momencie, kiedy zbuntował się przeciw Zenonowi ${ }^{39}$.

$\mathrm{W}$ tej sytuacji dysponujemy w zasadzie dwoma przekazami i to pochodzacymi mniej więcej $z$ tego samego i nieodległego od opisywanych wydarzeń czasu. Niestety nic konkretnego nie wiemy o źródłach informacji Eustacjusza z Epifanii i Pseudo-Jozuego Stylity. Sprawę tę kwituje się stwierdzeniem, że obaj autorzy, jako współcześni opisywanym wydarzeniom, swą wiedzę o nich budowali na podstawie informacji, które różnymi drogami docierały do nich jako do mieszkańców cesarstwa.

E.W. Brooks ${ }^{40}$, którego stanowisko w znacznej mierze zaważyło na poglądach innych badaczy, uznał za bliższa prawdy narrację Pseudo-Jozuego Stylity. Przyjął on, że Leoncjusz nie wyruszył na Wschód z Illusem, a przybył tam jako wysłannik Zenona, ale nie na czele dowodzonego przez siebie wojska, a dysponując ochrona w postaci oddziału Izauryjczyków ${ }^{41}$.

Nie wydaje się, że ta konstatacja musi być słuszna. Nie ma podstaw, żeby uznać, iż Eustacjusz z Epifanei dysponował mniej wiarygodnymi informacjami niż Pseudo-Jozue. Opowieść o zdradzie Leoncjusza, jego przekupieniu, którą znajdujemy u Pseudo-Jozuego Stylity, mogła być odpryskiem cesarskiej propagandy, w której Illusa i jego protegowanego ukazywano $z$ oczywistych powodów w czarnych barwach.

Eustacjusz z Epifanei - jak można wnosić ze źródeł z niego czerpiących - był krytycznie nastawiony do Zenona i $z$ tego względu mógł zawrzeć informacje, które były bliższe rzeczywistości. Wydaje się, że nie ma powodów, aby jednoznacznie odrzucić przekaz Eustacjusza, a tym samym nie uznać, że Leoncjusz mógł wyruszyć z Illusem

${ }^{39}$ Pseudo-Zachariasz Retor V, 6, f, VI, 6, e (The Chronicle of Pseudo-Zachariah Rhetor. Church and War in Late Antiquity, ed. G. Greatrex, transl. R.R. Phenix, C.B. Horn, with introductory material by S. Brock, W. Witakowski, Liverpool 2011).

${ }^{40}$ E.W. Brooks, op. cit., s. 226. Tę kwestię dyskutuja m.in.: M. Salamon, Pamprepiusz..., s. 183, przyp. 95; A. Ki el-Freytag, op. cit., s. 298; R. Ko siński, op. cit., s. 148.

${ }^{41}$ Jan $z$ Antiochii, 237.2. Na czele oddziału stali Izauryjczycy: Konon (na jego temat PLRE II, s. 306-307, Conon 4) i Lilingis (o nim: PLRE II, s. 683-684, Lilingis). 
z misja przywiezienia Weryny do Konstantynopola. Powierzonego mu przez cesarza zadania nie zrealizował. Możliwe, że stało się to pod naciskiem Illusa - tu byłaby pewna zbieżność $z$ przekazem Pseudo-Jozuego - i w ostateczności nie zdecydował się na powrót do Konstantynopola, pozostając w jego otoczeniu.

Niewykonanie przez Leoncjusza powierzonego mu przez cesarza zadania musiało zbliżyć go do Illusa i spowodować, że silniej związał swój los z losami tego ostatniego, choć w moim przekonaniu nie musiało to oznaczać ostatecznego zerwania z Zenonem. Jest możliwe, że misja Leoncjusza była tylko działaniem pozornym. Cesarzowi na pewno nie zależało na powrocie Weryny, a ugiął się jedynie pod presja cesarzowej Ariadny. Nie jest kwestią przypadku, że nie będzie domagał się później jej wydania, upominając się natomiast w sposób zdecydowany o odesłanie swojego brata - Longina. Oczywiście ten ostatni wątek może również oznaczać, że Leoncjusz misji przywiezienia Weryny do stolicy w ogóle nie otrzymał, a została mu ona jedynie przypisana przez Eustacjusza.

Funkcjonuje w nauce próba pogodzenia przekazów Eustacjusza i Pseudo-Jozuego Stylity, zgodnie $z$ która Leoncjusz miał dwukrotnie udawać się na Wschód. Po wyjeździe z Illusem miał powrócić do Konstantynopola ${ }^{42}$. Glanville Downey nie daje przekonującego wyjaśnienia, $z$ jakiego powodu Illus wrócił do Konstantynopola, by potem $z$ rozkazu cesarza raz jeszcze ruszyć na Wschód.

Wydaje się, że Leoncjusz i Illus musieli się znać wcześniej. Nie ma co prawda o tym mowy w źródłach, ale byłoby dziwne, gdyby magister officiorum, przez pewien czas druga osoba w państwie, i magister militum nie mieliby szansy spotkania się, a może i zadzierzgnięcia jakichś bliższych relacji ${ }^{43}$. To mogłoby też tłumaczyć gotowość Leoncjusza do wsparcia Illusa w wystąpieniu przeciw Zenonowi i przyjęcia cesarskiej purpury. Leoncjusz i Illus musieli darzyć się choćby elementarnym zaufaniem, co bez wczesniejszych kontaktów byłoby chyba trudne do uzyskania. Nie przekonuje mnie tłumaczenie zwolenników wiarygodności przekazu Pseudo-Jozuego Stylity, że Leoncjusz został proklamowany na cesarza w nagrodę za zdradę i przejście na stronę Illusa ${ }^{44}$. Udział

${ }^{42}$ G. Downey, op. cit., s. 490-491, przyp. 73 i s. 494, przyp. 96; M. Salamo n, Pamprepiusz..., s. 183, przyp. 95.

${ }_{43}$ Tak też M. Sala mo n, Pamprepiusz..., s. 183.

44 Przykładowo: R. Kosińs ki, op. cit., s. 148. 
w przedsięwzięciu, które w razie niepowodzenia - czego przecież nie można byłoby wykluczyć - musiało zakończyć się śmiercią, trudno uznać za nagrodę.

Tak czy inaczej otwarte pozostaje pytanie o motywy decyzji Leoncjusza. Źródła nie daja żadnych podstaw do dyskutowania tej sprawy. Jeśli przyjmiemy, że Leoncjusz wyruszył z Illusem na Wschód, to miał sporo czasu, by poznać plany Illusa i rozważyć swój w nich udział. Nie byłaby więc to najpewniej decyzja chwili, jakby musiało być w powyżej rozpatrywanym wątku zdrady, a przemyślany krok. Leoncjusz, jako człowiek doświadczony i majac rozeznanie w sytuacji, uznał, że istnieje szansa na sukces wystapienia przeciw Zenonowi.

Najważniejszy dzień życia Leoncjusza - moment cesarskiej proklamacji - nastapił 19 lipca 484 r. w kościele św. Pawła na przedmieściach Tarsu ${ }^{45}$. Pod względem formalnym najważniejszą rolę w proklamacji cesarskiej Leoncjusza odegrała Weryna, która pozyskana została do sprawy buntu. Dokonała ona koronacji Leoncjusza. Być może wygłosiła wówczas przemowę, później wysłaną do mieszkańców Antiochii, jak również zarządców Wschodu, Egiptu, Libii, a w której uzasadniała wyniesienie do tronu Leoncjusza. Wdowa po Leonie I twierdziła, że to do niej należy władza cesarska. Przekazała ja po śmierci Leona I, swojego męża, Zenonowi. To $z$ jej woli został on cesarzem, by poprawić los poddanych i wzmocnić państwo. Cel przed nim postawiony nie został jednak zrealizowany. Sprawy państwa zostały zaniedbane $z$ powodu chciwości władcy (aplestia). W tej sytuacji Weryna postanowiła pozbawić go władzy i ogłosić nowego cesarza. Twierdziła, że może to uczynić, ponieważ to ona wyniosła go na tron. Dodała również - co w kontekście omawianego problemu nabiera szczególnego znaczenia - że proklamuje chrześcijańskiego cesarza wyróżniającego się pobożnością i sprawiedliwościa ${ }^{46}$. Takim miał być właśnie Leoncjusz, określony w inkryminowanym dokumencie mianem „najpobożniejszy” (eusebestatos) ${ }^{47}$. Takie postawienie sprawy mogło sugerować, że Zenon,

45 Por. m.in.: Jan Malalas, XV, 13; Jan z Antiochii, 237.2; Teofanes, AM 5973-5974, s. 128-129; Pseudo-Jozue Stylita, 15 (jako miejsce cesarskiej proklamacji Leoncjusza podaje Antiochię).

${ }_{46}$ Teodor Lektor, 437; Te ofanes, AM 5973-5974, s. 128-129; Jan Malalas, XV, 13; por. Jan Z Nikiu, 88.80-81, s. 119; Jan z Antiochii, 237.2.

47 Jan Malalas, XV, 13; Te ofanes, AM 5974, s. 129; por. Jan z Nikiou, 88, 81, s. 119 (Christian Godloving man). 
obecnie panujący cesarz, nie wykazuje się właściwa postawą religijną. Bezpośrednich zarzutów odnoszących się do religijności władcy jednak nie sformułowała ${ }^{48}$. Niektórzy uczeni interpretowali podkreślenie pobożności Leoncjusza jako wyraz odcięcia się od polityki religijnej Zenona, której ostatnim przejawem było opublikowanie w roku 482 tzw. Henotikonu, obliczonego na zawarcie kompromisu między zwolennikami a przeciwnikami soboru w Chalcedonie ${ }^{49}$. W świetle najnowszych badań taka interpretację należy jednak odrzucić ${ }^{50}$. Wydaje się, że podkreślenie pobożności nowego władcy wpisuje się po prostu w kanon cech, którymi winien się charakteryzować cesarz. Eusebeia była warunkiem dobrych rządów ${ }^{51}$. Podanie w wątpliwość pobożności Zenona wydaje się logiczną konsekwencją uznania go za złego władcę. Co znamienne, watek ten miał również wypłynąć - jeśli wierzyć przekazowi dzieła O ceremoniach Konstantyna Porfirogenety - po śmierci tego cesarza. Zgromadzony

48 Słusznie podkreśla R. Kosiński (op. cit., s. 151), że Weryna nie zarzucała Zenonowi odejścia od ortodoksji, a upatrywała słabości jego rządów przede wszystkim czy wręcz jedynie w chciwości. Oskarżenie o chciwość dobrze wpisuje się w repertuar zarzutów kierowanych pod adresem „złych” władców. Szerzej na temat kaiserkritik: F. Tinnefeld, Kategorien der Kaiserkritik in der byzantinischen Historiographie von Prokop bis Nicetas Choniates, Münich 1971.

${ }^{49} \mathrm{Na}$ temat Henotikonu vide m.in. R. Kos iński, Kilka uwag o Henotikonie $i$ domniemanym zwrocie $w$ polityce religijnej cesarza Zenona, [w:] Społeczeństwo $i$ religia $w$ świecie antycznym. Materiały $z$ ogólnopolskiej konferencji naukowej (Toruń, 20-22 września 2007 r.), red. S. Olszaniec, P. Wojciechowski, Torun 2010, s. 433-451 (tam dalsza literatura). Jako wystapienie przeciw Henotikonowi postrzegali uzurpację Illusa i Leoncjusza m.in. E.W. Brooks, op. cit., s. 227 i W.H.C. Frend, The Rise of Monophysite Movement. Chapters in the History of the Church in the Fifth and Sixth Centuries, Cambridge 1972, s. 181. Por. H. E1to n, op. cit., s. 402 (określa reskrypt Weryny jako „Chalcedonian”); K. Tw a rdowska, op. cit., s. 140 (twierdzi, idąc zdecydowanie za daleko, że „w piśmie wydanym przez siebie zarzuciła Zenonowi, że popiera herezję monofizycka””).

${ }^{50}$ H.Ch. Brennecke, Chalkedonense und Henotikon. Bemerkungen zur Prozess der östlichen Rezeption ser christologischen Formel von Chalkedon, [w:] Chalkedon: Geschichte und Aktualtät. Studien zur Rezeption der christologischen Formel von Chalkedon, hrsg. J. van Oort, J. Roldanus, Leuvain 1997, s. 48; R. Kosińs ki, Kilka uwag..., s. 442-443; id e m, The Emperor Zeno..., s. 150-151.

${ }^{51}$ Przykładowo: W. Ceran, Cesarz $w$ teologii politycznej Euzebiusza z Cezarei i nauczaniu Jana Chryzostoma, „Acta Universitatis Lodziensis. Folia Historica” 1992, z. 44, s. 13-27; K.G. Pits akis, Sainteté et empire. A propos de la sainteté impériale: formes de sainteté "d'office" et de sainteté collective dans l'Empire d'Orient, „Bizantinistica” 2002, t. III, s. 156; D. F eis s e1, Cesarz i administracja cesarska, [w:] Świat Bizancjum, t. I (Cesarstwo wschodniorzymskie 330-641), red. C. Morrisson, przekł. A. Graboń, Kraków 2007, s. 97. 
w hipodromie lud żądał wyboru prawowiernego władcy ${ }^{52}$ i do tego nieulegającego chciwości, ani innym ludzkim przypadłościom ${ }^{53}$. W kontekście przedstawionych rozważań wydaje się, że podkreślenie pobożności Leoncjusza było spowodowane nie tyle chęcia krytyki tej sfery osobowości czy rządów Zenona, ile raczej potrzeba wskazania w sposób czytelny i łatwo przemawiający do odbiorcy, że nowy cesarz będzie lepszy od obecnego.

Dzięki udziałowi cesarzowej-wdowy buntownicy tworzyli pozory legalności cesarskiej proklamacji Leoncjusza. Po uroczystościach w Tarsie Leoncjusz i Illus wraz ze swoimi ludźmi udali się do Antiochii, która miała stanowić ich siedzibę.

Przywódcy buntu mieli świadomość, że ich ewentualny sukces zależny był od wyniku rozprawy zbrojnej $z$ siłami cesarskimi. Illus, jako magister militum per Orientem, dysponował regularnymi oddziałami wojskowymi. Należy pamiętać, że w armii obowiązywała dyscyplina, w konsekwencji której o postawie szerokich mas żołnierskich decydowała kadra dowódcza. A do niej najłatwiej było trafić za pomoca „złota” i obietnic awansów. Mógł liczyć na przynajmniej część swoich izauryjskich pobratymców. Illus zamierzał również wykorzystać aparat państwa na obszarze, na którym rozciągała się jego władza, wiemy również, że dążył do pozyskania wsparcia zewnętrznego. Jego wysłannicy zostali skierowani do władców armeńskich, Persji i do Odoakra, rządzącego Italią ${ }^{54}$.

$Z$ uzurpacją Illusa i Leoncjusza wiąże się kwestię potencjalnego wsparcia dla niej ze strony kręgów pogańskich ${ }^{55}$. Sprawa ta była już wielokrotnie dyskutowana. Źródła notują ożywienie nadziei

52 Konstantyn Porfirogeneta (Constantine Porphyrogennetos, The Book of Ceremonies, transl. A. Moffat, M. Tall with the Greek edition of the Corpus Scriptorum Historiae Byzantinae [Bonn 1829], vol. I-II, Canberra 2012), I, 92 , s. 418.

53 Analiza tego przekazu: M.J. Les zka, Uzurpacje $w$ cesarstwie bizantyńskim w okresie od IV do połowy IX wieku, Łódź 1999, s. 19-20; por. K. Tw ar d ow s ka, op. cit., s. 92-93.

${ }^{54}$ Jan $z$ Antiochii, 237.2; por. Pseudo-Jozue Stylita, 15, s. 14 (wysłanie posłów do władcy perskiego); Prokopiusz (Procopius, On Buildings, III, 1, transl. H.B. Dewing, London 1940), III, 1. Do Odoakra z poselstwem wysłany został Marcjan. Zakończyło się ono niepowodzeniem. Władca perski, co prawda, obiecał wsparcie, ale się z obietnicy nie wywiazał (M.J. Leszka, Uzurpacje..., s. 104; R. Kosińs ki, The Emperor Zeno..., s. 147-148).

${ }_{55} \mathrm{Na}$ ten temat pisałem szerzej $\mathrm{w}$ artykule: Watki religijne $w$ propagandzie wczesnobizantyńskich uzurpatorów. Przypadek Illusa i Leoncjusza (484), „Christianitas antiqua” 2014, nr 6, s. 188-193. 
pogan na poprawę własnej sytuacji ${ }^{56} . Z$ pewnością nie zostały one wywołane tym, że Illus i Leoncjusz wpisali w swój program odrodzenie religii pogańskiej - wręcz przeciwnie, w swojej propagandzie odwoływali się do chrześcijaństwa, o czym szczególnie dobrze świadczy przedstawiony powyżej reskrypt Weryny ${ }^{57}$, jak również wsparcie Kalandiona, patriarchy Antiochii ${ }^{58}$.

Czy w sferze propagandowej jakieś pozytywne sygnały zostały wysłane do środowisk pogańskich? Wydaje się, że $z$ oczywistych względów niczego takiego nie uczyniono ${ }^{59}$. Pomijając już postawę religijną inspiratorów buntu, to otwarte odwoływanie się do pogan z pewnościa przyczyniłoby Illusowi i Leoncjuszowi więcej kłopotów niż zysku, musiałoby to bowiem, co oczywiste, niechętnie nastawić do tych ostatnich szerokie rzesze chrześcijan. Dlaczego więc doszło w dobie uzurpacji do ożywienia nadziei pogan? Jak można sądzić, wiązały się one $z$ obecnością w bliskim otoczeniu przywódców buntu Pamprepiusza, wyznawcy pogańskich kultów. Ten poeta, retor, a także wieszcz cieszył się sporym poważaniem Illusa,

${ }^{56}$ Wiemy, że takie nadzieje obecne były m.in. w środowisku pogan w Palestynie (Zach arias, Vita Isaiae Monachi, [w:] Vitae virorum apud monophysitas celeberrimorum, ed. E.W. Brooks, Louvain 1955, s. 7; M. Salamo n, Pamprepiusz..., s. 187; R. Kosiński, The Emperor Zeno..., s. 164-165). W mieście Afrodyzjas w Karii przeprowadzano wróżby w celu ustalenia, jakie będą losy wystąpienia Illusa, Leoncjusza i Pamprepiusza: „ile ofiar złożyliśmy, jako poganie, w Karii, bogom pogańskim, kiedy prosiliśmy ich, tych niby-bogów, rozcinając wątroby i badając je za pomoca magii, żeby powiedzieli nam, czy z Leoncjuszem, Illusem i Pamprepiuszem, i z tymi wszystkimi, którzy zbuntowali się z nimi, uda nam się pod ich nabożną egidą zwyciężyć cesarza Zenona. Ileż przyszło przepowiedni i obietnic, jakoby cesarz Zenon nie wytrzyma ich ataku, że przyszedł już moment, kiedy chrześcijaństwo się rozpadnie i zniknie, a wtedy kulty pogańskie znów powróca" (Zachariasz Scholastyk, Vita Severi, [w:] Zacharie le Scholastique, Vie de Sévére, ed. M.-A. Kugener, Paris 1903, s. 40; cyt. za: P. Chuvin, Ostatni poganie. Zanik wierzeń pogańskich $w$ cesarstwie rzymskim od panowania Konstantyna do Justyniana, przekł. J. Stankiewicz-Prądzyńska, Warszawa 2008, s. 118). O sytuacji pogan w Afrodyzjas por. F.R. Trombley, Hellenic Religion and Christianization c. 370-529, vol. I, Leiden-New York-Köln 1993, s. 52-69; R. Kosiński, The Emperor Zeno..., s. 157.

57 Nie ma wątpliwości, że zarówno Illus, jak i Leoncjusz byli chrześcijanami. Na temat religijności Illusa: H. E1to n, op. cit., s. 402-403.

58 R. Kosiński, The Emperor Zeno..., s. 147

59 Na ten temat ostatnio: M. Vallej o-Girvés, Empress Verina among the Pagans, [w:] Pagans and Christians in the Late Roman Empire. New Evidence, New Approaches $\left(4^{\text {th }}-8^{\text {th }}\right.$ centuries), eds M. Sághy, E.M. Schoolman, Budapest 2017, s. 52-58. 
który od 476 r. był jego opiekunem i mentorem ${ }^{60}$. Po proklamacji Leoncjusza otrzymał on nawet urząd magistra officiorum. Pełnienie przez poganina tak wysokiego urzędu mogło sugerować, że Illus i Leoncjusz, choć chrześcijanie, będą otwarci na podjęcie kroków zmierzających do poprawy sytuacji wyznawców starych kultów.

Wiemy, że w przededniu buntu Pamprepiusz przebywał w Aleksandrii, gdzie kontaktował się $z$ przedstawicielami miejscowych pogan. Należy jednak wattpić, żeby wtajemniczył ich w plany swojego protektora, choć nie można wykluczyć, że wątek napiętych relacji między Illusem a cesarzem Zenonem został w czasie rozmów podjęty $^{61}$. O innych krokach Pamprepiusza w środowiskach pogańskich nic nie wiemy.

Po przybyciu do Antiochii, gdzie zostali dobrze przyjęci ${ }^{62}$, Leoncjusz i Illus rozpoczęli formowanie zrębów swojej administracji. Wiadomo, że Elian został wyznaczony na prefekta pretorium, Pamprepiusz został magistrem officiorum, a Justynian komesem sacrarum largitionum ${ }^{63}$. Wydaje się, że Illus dla siebie i Trokundesa, swojego brata, zawarował stanowiska magistrów militum ${ }^{64}$. Władza nad wojskiem gwarantowała im zachowanie wpływów w razie ostatecznego sukcesu w zmaganiach $z$ cesarzem.

Antiochia pozostawała w rękach buntowników około dwóch miesięcy. Nie oznacza to, że sam Leoncjusz przez ten czas w niej

${ }^{60} \mathrm{Na}$ temat Pamprepiusza por. M. Salamon, Pamprepiusz..., s. 163-195; K. Feld, Pamprepius. Philosoph und Politiker oder Magier und Aufrührer?, [w:] Gelehrte in der Antike. Alexander Demandt zum 65. Geburtstag, hrsg. A. Goltz, A. Luther, H. Schlange-Schöningen, Köln-Wiemar-Wien 2002, s. 261-280.

${ }^{61}$ Misja odbyła się zapewne pod koniec 483 r. Warto zwrócić uwage na to, że Pamprepiusz miał nie wzbudzić pozytywnych odczuć u swoich interlokutorów (Damascius, The Philosophical History, 112 A, 113 O, ed. P. Athanassiadi, Athens 1999). Kwestię jego pobytu w Aleksandrii analizują m.in. M. Salamon, Pamprepiusz..., s. 179-180; R. Kosińs ki, The Emperor Zeno..., s. 155-156.

${ }^{62}$ Illus już wcześniej działał na rzecz uzyskania wsparcia antiocheńczyków, prowadząc intensywna akcję budowlana - por. G. Downey, op. cit., s. 491.

${ }^{63}$ Por. M. Salamo n, Pamprepiusz...., s. 186.

${ }^{64}$ Śladem pełnienia przez Trokundesa i Illusa stanowisk magistri militum może być przekaz Jana $z$ Antiochii (237.5), w którym znajdujemy informację, że przeciw wojskom cesarskim zostali wysłani Papimus, dowódca jazdy Illusa,

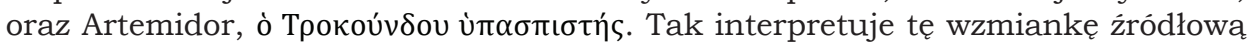
W. Barth, Kaiser Zeno, Basel 1894, 87 (który w Artemidorusie widzi dowódcę piechoty); J. Kulakovskij, op. cit., s. 430; M. Sala mo n, Pamprepiusz..., s. 186, przyp. 114; inaczej PLRE II, s. 155, 831 - wspomniani Papimus i Artemidor nie tyle dowodzili wojskami, co zostali wysłani do Zenona $z$ misją dyplomatyczna. 
przebywał. Malalas mówi, że rządził w Antiochii przez niewiele dni

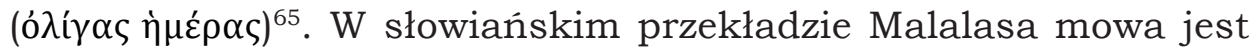
o 12 dniach $^{66}$. Po nich, jak można mniemać, uczestniczył w oblężeniu Chalkis ${ }^{67}$. Z oporem spotkał się Leoncjusz w Edessie, która nie wpuściła oddziału dowodzonego przez Matroniana ${ }^{68}$.

Zenon wysłał przeciw buntownikom wojska pod dowództwem Jana Scyty ${ }^{69}$. Do decydujacej bitwy doszło prawdopodobnie pod koniec drugiej dekady września 484 r. ${ }^{70}$ Nie jest znane dokładne miejsce potyczki. Niektórzy badacze sugerują, że doszło do niej w okolicach Antiochii ${ }^{71}$, ale najprawdopodobniej stoczono ja gdzieś na terenie Izaurii ${ }^{72}$, może w pobliżu Seleucji ${ }^{73}$. Nie znamy jego przebiegu, poza stwierdzeniem, które znajdujemy u Pseudo-Jozuego Stylity, że: „John hit them [tj. ludzi Illusa - M.J.L.] hard and destroyed the bulk of their army [...] Being unable to resist attack, (the conspirators) took the remnant of their force and fled to secure and well-supplied fortress" ${ }^{\prime 4}$. Jak można sązić, w bitwie tej Illus stracił gros swoich sił i utracił możliwość skutecznego dalszego oporu. Co prawda Jan z Antiochii donosi, że Leoncjusz, który nie uczestniczył $\mathrm{w}$ bitwie, dysponował jeszcze dwoma tysiącami żołnierzy, ale na wieść o jej wyniku wybrał $z$ nich najbardziej lojalnych, a resztę rozpuścił, żeby schronili się w trudno dostępnych miejscach ${ }^{75}$. Leoncjusz i Illus zamknęli się w twierdzy Papyrion, do której dostęp był niezwykle utrudniony ${ }^{76}$. Jak donosi Teofanes

\footnotetext{
65 Jan Malalas, XV, 13.

66 Jan Malalas (słow.), s. 341.

67 Teofanes, AM 5976, s. 129.

${ }^{68}$ Pseudo-Jozue Stylita, 16.

${ }^{69} \mathrm{Na}$ temat Jana Scyty por. M.J. Leszka, John the Scythian - a Slayer of usurpers and the Isaurians, „Studia Ceranea” 2020, vol. X, s. 383-397.

${ }^{70} \mathrm{Na}$ temat datowania bitwy: M.J. Les zka, The Career of Flavius Appalius Illus Trocundes, „Byzantinoslavica” 2013, t. LXXI, s. 57.

${ }^{71}$ PLRE II, s. 602; K. Twardowska, Rzymski Wschód w latach 395-518, [w:] Świat rzymski w V wieku, red. R. Kosiński, K. Twardowska, Kraków 2010, s. 111. Por. P. Craw ford, op. cit., s. 198-199.

${ }^{72}$ G. Downey, op. cit., s. 495-496, przyp. 105; R. Kosiński, The Emperor Zeno..., s. 149.

${ }^{73}$ R.C. M c Cail, P. Gr. Vindob. 29788C: hexameter encomium on an un-named emperor, „Journal of Hellenic Studies” 1978, vol. XCVIII, s. 54.

${ }^{74}$ Pseudo-Jozue Stylita, 17, s. 15.

75 Jan $z$ Antiochii, 237.5.

${ }^{76} \mathrm{Na}$ jej temat por. J. Gottwald, Die Kirche und das Schloss Paperon in Kilikisch-Armenien, „Byzantinische Zeitschrift” 1936, Bd. XXXVI, s. 86-100; F. Hild,
} 
Trokundesowi, bratu Illusa powierzona została misja dokonania zaciagów wśród barbarzyńców ${ }^{77}$. Przez chwilę buntownicy mieli jeszcze nadzieję - którą podsycać miał Pamprepiusz, magister officiorum Leoncjusza, wieszcz i filozof - że dzięki jego skutecznej akcji odzyskają inicjatywę w zmaganiach $z$ siłami cesarskimi ${ }^{78}$. Misja się jednak nie powiodła. Trokundes został pojmany przez ludzi Jana Scyty i z jego rozkazu stracony ${ }^{79}$. Śmierć Trokundesa należy, jak się wydaje, datować na środek listopada 484 r. ${ }^{80}$ Jan Scyta, chcąc złamać ducha oblężonych, zapewne zadbał, aby wieść o niej dotarła jak najszybciej do Papyrion. Obrońcy twierdzy w obliczu tragicznej informacji nie zdecydowali się jednak na poddanie, a swoja frustrację zwrócili przeciw Pamprepiuszowi, nieszczęsnemu wieszczowi, który został stracony ${ }^{81}$.

Wojska cesarskie oblegały twierdzę Papyrion jeszcze przez prawie cztery lata (do 488 r.). Leoncjusz miał świadomość, że zdobycie twierdzy oznaczać będzie dla niego śmierć. Nie mógł liczyć na łaskę cesarza, o czym dobitnie świadczyło fiasko próby negocjacji $z$ nim Illusa, o której informuje Jan $z$ Antiochii ${ }^{82}$. Nic dziwnego, że w takiej sytuacji, jak donosi Jan $z$ Antiochii, że Leoncjusz spędzał czas na postach i lamentowaniu ${ }^{83}$.

Do zdobycia twierdzy doszło w wyniku zdrady. Tym, który wydał twierdzę, miał być szwagier Trokundesa. Tak twierdzi Teofanes ${ }^{84}$. Chronograf nie podaje jednak jego imienia. Inne źródła donosza, że

H. Hellenkemper, op. cit., s. 374-375. W Papyrion znaleźli schronienie także inni uczestnicy buntu, m.in. Weryna i Marsus, którzy zmarli w początkach oblężenia.

77 Teofanes, AM 5976. Trudno orzec, kogo ma na myśli chronograf, używając określenia „barbarzyńcy”. Nie ma to jednak z perspektywy rozwoju sytuacji żadnego znaczenia, ponieważ misja zakończyła się niepowodzeniem.

78 Teofanes, AM 5976.

79 Te ofanes, loc. cit.

${ }^{80}$ M.J. Les zka, The Career..., s. 56-57. Na rok 485 wskazuje, bez uzasadnienia, Peter Crawford, op. cit., s. 200.

${ }^{81}$ Na ten temat: M. Sala m o n, Pamprepiusz..., s. 191; K. Feld, Pamprepius..., s. 269,277 , przyp. 66 .

82 Jan $z$ Antiochii, 237.7.

83 Jan z Antiochii, 237.6. Gdyby uznać przekaz Jana za prawdziwy, świadczyłoby to o słabości charakteru Leoncjusza, od którego jako wodza i kandydata na cesarza można by wymagać bardziej mężnej postawy.

${ }_{84}$ Teofanes, AM 5980; E.W. Brooks, op. cit., s. 229. Powody zdrady por. N. Lenski, Assimilation and Revolt in the Territory of Isauria, from $1^{\text {st }}$ Century $B C$ to the $6^{\text {th }}$ Century $A D$, „Journal of the Economic and Social History of the 
zdrajca miał być Indakus Kottounes ${ }^{85}$, więc być może to on był bratem nieznanej $z$ imienia żony Trokundesa. Żadne źródło nie mówi wprost, że Indakus Kottounes był szwagrem Trokundesa. Pogląd ten jest próbą pogodzenia wskazanych powyżej tradycji źródłowych. W niektórych źródłach występuje wątek zdrady bez określenia osoby (osób), która (które) się jej dopuściła (dopuściły) ${ }^{86}$. Część źródeł odnotowuje zdobycie Papyrion bez podawania szczegółów ${ }^{87}$.

Do zdobycia Papyrion doszło w nocy. Jak informuje Jan $z$ Antiochii, Leoncjusz i Illus obudzeni zostali tradycyjna cesarska

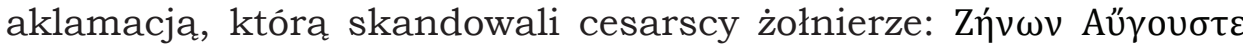
$\tau o u ́ \mu \beta \iota \kappa \alpha \varsigma^{88}$. Wiedzac, co to dla nich oznacza, Leoncjusz i Illus szukali schronienia w świątyni św. Konona. Leoncjusz chciał popełnić samobójstwo, ale został powstrzymany przez Illusa. Nieszczęśnicy zostali wyciagnięci siła $z$ kościoła i po wyprowadzeniu $z$ twierdzy, modlących się ścięto. Towarzyszyć temu miały gwałtowne zjawiska pogodowe (błyskawice, grad, silny wiatr). Głowy Leoncjusza i Illusa zostały wysłane do Konstantynopola, gdzie $z$ rozkazu Zenona wbito je na pale i wystawiono ku pohańbieniu na widok publiczny ${ }^{89}$. Taki dramatyczny obraz wydarzeń po zdobyciu Papyrion daje jedynie Jan $z$ Antiochii. Czy jest on zgodny z rzeczywistością? $\mathrm{Na}$ to pytanie, przy braku innych źródeł szerzej przedstawiających te sytuację, odpowiedzieć się nie da. Pewne wątpliwości co do prawdziwości tego opisu może rodzić nieco „teatralny” sposób ukazania ostatnich chwil Leoncjusza i Illusa, i ich otoczenia. Pozostałe źródła notuja jedynie zdobycie twierdzy i stracenie buntowników ${ }^{90}$. Pseudo-Jozue Stylita dorzuca jedynie, że decyzję o ich egzekucji

Orient” 1999, vol. XLII, s. 253. Por. Te od or Lektor, 438 (za zdradą stać miała żona Trokundesa).

85 Jan $z$ Antiochii, 237.10.

${ }^{86}$ Przykładowo: Pseudo-J ozue Stylita, 17, s. 16. Indakusa Kottounesa za szwagra Trokundesa uznawali np. E.W. Brooks, op. cit., 229; W.D. Burges s, Isaurian Factions in the Reign of Zeno the Isaurian, "Latomus” 1992, vol. LI, s. 878 .

87 Przykładowo: Marcellinus Komes, a. 488.1; Jordanes, Romana, 353 (mowa o ścięciu i wysłaniu głów do Konstantynopola).

88 Jan $z$ Antiochii, 237.10.

89 Jan $z$ Antiochii, 237.11.

90 Teodor Lektor, 437; Teofanes, AM 5980, s. 133; Wiktor z Tunnuny (Vittore da Tunnuna, Chronica. Chiesa e impero nell' età di Giustiniano, a cura di A. Placanica, Firenze 1997), a. 488 (mówi o zdradzie i najhaniebniejszej śmierci); Kandyd Izauryjczyk, s. 470; Pseudo-Zachariasz Retor, V, 9, c; VI, 6, e. 
podjął sam cesarz ${ }^{91}$. Z kolei Jan Malalas twierdzi, że stało się to $z$ woli zarządcy Seleucji Izauryjskiej ${ }^{92}$. Bez względu na drobne różnice dotyczące osób bezpośrednio odpowiedzialnych za stracenie Leoncjusza i Illusa jedno jest pewne - że taka była wola cesarza. Zapewne Zenon jednoznacznie polecił oblegającym, co maja zrobić $z$ przywódcami buntu po zdobyciu Papyrion. Ich wina była bezdyskusyjna. Za nia obowiązywała tylko jedna kara - śmierć, o ile cesarz nie chciałby $z$ jakichś względów postąić inaczej.

W ten dramatyczny sposób zakończyły się losy bohatera niniejszego tekstu. Represje dotknęły także innych uczestników buntu.

$$
* * *
$$

W słowiańskim przekładzie Jana Malalasa zachował się opis powierzchowności i osobowości Leoncjusza: „Б' жє Пєшнтии красєнт

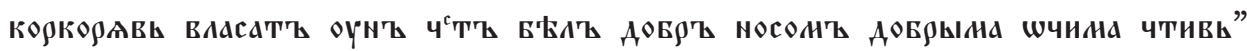
(„Był bowiem Leoncjusz piękny, o kędzierzawych włosach, młody, prawy, o jasnej cerze, mogacy się poszczycić ładnym nosem i ładnymi oczami" ${ }^{93}$. Trzeba przyznać, że jest on dla mojego bohatera pozytywny. Trudno jednak powiedzieć, na ile oddaje rzeczywistość. Zapewne opis ten znajdował się w nieznanej nam dzisiaj wersji Chronografii Jana Malalasa, którą musiał dysponować słowiański tłumacz. Jeśli tak, to opis Leoncjusza - podobnie jak inne pojawiajace się u Malalasa portrety - zostal zbudowany na podstawie zasad starożytnej nauki, zwanej fizjonomika, według których powierzchność człowieka była odzwierciedleniem jego wnętrza ${ }^{94}$.

$$
* * *
$$

Źródła uchwyciły Leoncjusza na przestrzeni ledwie kilku lat, kiedy zaangażował się w walkę o cesarski tron. Do tego momentu jego kariera o charakterze wojskowym rozwijała się zapewne bez specjalnych zawirowań. Osiagnał wysokie stanowisko w armii - magister militum per Thracias, obdarzony został przez cesarza tytułem

${ }^{91}$ Pseudo-Jozue Stylita, 17, s. 16. Represje dotknęły także innych sprzymierzeńców Illusa i Leoncjusza, którzy znajdowali się w twierdzy.

${ }_{92}$ Jan Malalas, XV, 14.

${ }^{93} \mathrm{Jan}$ Malalas (słow.), s. 341.

${ }_{94} \mathrm{Na}$ temat portretowania postaci w dziele Jana Malalasa por. M. Kokos zko, Descriptions of Personal Appearance in John Malalas' Chronicle, Łódź 1998. 
patrycjusza i konsula honorowego. Czym się wykazał, że zasłużył na takie awanse - nie wiemy. Jest prawdopodobne, że gdyby nie wystapienie przeciw Zenonowi, inspirowane przez Illusa, to imię Leoncjusza nie pojawiłoby się na kartach źródeł. To ono spowodowało, że ich autorzy zainteresowali się jego postacią, ale - jak się wydaje - nie dysponowali dostępem do jakichś bogatszych i spójnych informacji.

Leoncjusz urodził się zapewne w rodzinie należącej do kręgów prowincjonalnej arystokracji, co umożliwiło mu odebranie dobrego wykształcenia. Co do pochodzenia etnicznego, to wbrew dość powszechnej w nauce opinii, że pochodził z Izaurii, trzeba wskazać, że równie dobrze można uznać, że wywodził się z Syrii (o czym bezpośrednio mówi Teofanes). Co do pełnienia przez niego stanowiska magister militum per Thracias, to wydaje się, że mógł je sprawować w latach 478-482 (nie ma pewności, że był nim w 484 r.). Najpewniej znał się $z$ Illusem jeszcze przed 481/482 r. i z nim wyruszył na Wschód, gdy ten przejmował stanowisko magister militum, i pozostał u jego boku do 484 r., kiedy wybuchł otwarty konflikt $z$ Zenonem. Leoncjusz został proklamowany cesarzem, ponieważ Illus nie chciał nim zostać. Wydaje się, że ten ostatni cenił Leoncjusza i darzył go zaufaniem.

Po chwili triumfu w dniu cesarskiej koronacji (19 lipca 484 r.) Leoncjusz raptem w dwa miesiące później - po klęsce sił dowodzonych przez Illusa w bitwie $z$ siłami cesarskimi - musiał schronić się w twierdzy Papyrion, w której spędził około czterech lat, czekając na śmierć. Ta ostatnia spotkała go $z$ rąk cesarskich żołnierzy w $488 \mathrm{r}$.

\section{Bibliografia}

\section{$\dot{Z}_{\text {RÓDEA DRUKOWANE }}$}

Candidus, Fragmenta, [w:] The Fragmentary Classicising Historians of the Later Roman Empire. Eunapius, Olympiodorus, Priscus and Malchus, ed. R.C. Blockley, vol. II, Liverpool 1983, s. 464-473.

Constantine Porphyrogennetos, The Book of Ceremonies, transl. A. Moffat, M. Tall, with the Greek edition of the Corpus Scriptorum Historiae Byzantinae (Bonn 1829), vol. I-II, Canberra 2012.

Damascius, The Philosophical History, ed. P. Athanassiadi, Athens 1999. 
Ioannis Antiocheni Fragmenta quae Supersunt Omnia, rec. S. Mariev, Berolini et Novi Eboraci 2008.

Ioannis Malalae chronographia, rec. J. Thurn, Berolini et Novi Eboraci 2000.

Istrin V.M., Hronika Ioanna Malaly v slavjanskom perevode, Moskva 1994.

Jordanes, Romana, [w:] Monumenta Germaniae Historica. Auctores antiquissimi, t. V, pars prior, ed. Th. Mommsen, Berolini 1882, s. 1-52.

Liberatus, Breviarium cause Nestorianorum et Eutychianorum, 17, [w:] Acta Oecumenicorum Conciliorum, ed. E. Schwartz, t. II, vol. 5, Berolini-Lipsiae 1936, s. $98-141$.

Malchus, Testimonia, [w:] The Fragmentary Classicising Historians of the Later Roman Empire. Eunapius, Olympiodorus, Priscus and Malchus, ed. R.C. Blockley, vol. II, Liverpool 1983.

Procopius, On Buildings, transl. H.B. Dewing, London 1940.

The Chronicle of John, bishop of Nikiu, transl. R.H. Charles, Oxford 1916.

The Chronicle of Marcellinus. A Translation and Commentary (with a reproduction of Mommsen' edition of the text) B. Croke, Sydney 1995.

The Chronicle of Pseudo-Joshua the Stylite, transl., notes and introduction F.R. Trombley, J.W. Watt, Liverpool 2000.

The Chronicle of Pseudo-Zachariah Rhetor. Church and War in Late Antiquity, ed. G. Greatrex, transl. R.R. Phenix, C.B. Horn, with introductory material by S. Brock, W. Witakowski, Liverpool 2011.

The Ecclesiastical History of Evagrius with scholia, ed. J. Bidez, L. Parmentier, London 1898; przekł. pol.: Ewagriusz Scholastyk, Historia Kościoła, przekł.

S. Kazikowski, wstęp E. Wipszycka, Warszawa 1990.

Theodoros Anagnostes, Kirchengeschichte, Epitome, hrsg. G.C. Hansen, Berlin 1995.

Vittore da Tunnuna, Chronica. Chiesa e impero nell' età di Giustiniano, a cura di A. Placanica, Firenze 1997.

Zacharias, Vita Isaiae Monachi, [w:] Vitae virorum apud monophysitas celeberrimorum, ed. E.W. Brooks, Louvain 1955, s. 1-10.

Zacharie le Scholastique, Vie de Sévére, ed. M.-A. Kugener, Paris 1903.

\section{OpRacowania}

Allen P., Evagrius Scholasticus the Church Historian, Leuven 1981.

Bagnall S.R., Cameron A., Schwartz R.S., Worp Klaas A., Consuls of the Later Roman Empire, Atlanta 1987.

Barth W., Kaiser Zeno, Basel 1894.

Begass Ch., Die Senatsaristokratie des oströmischen Reiches, ca. 457-518. Prosopographische sozialgeschichtliche Untersuchungen, München 2018.

Brennecke H.Ch., Chalkedonense und Henotikon. Bemerkungen zur Prozess der östlichen Rezeption ser christologischen Formel von Chalkedon, [w:] Chalkedon: Geschichte und Aktualtät. Studien zur Rezeption der christologischen Formel von Chalkedon, hrsg. J. van Oort, J. Roldanus, Leuvain 1997, s. 24-53. 
Brooks E.W., The Emperor Zeno and the Isaurians, „English Historical Review” 1893, vol. VIII, s. 209-238.

Burgess W.D., Isaurian Factions in the Reign of Zeno the Isaurian, „Latomus” 1992, vol. LI, s. 874-880.

Ceran W., Cesarz $w$ teologii politycznej Euzebiusza z Cezarei i nauczaniu Jana Chryzostoma, „Acta Universitatis Lodziensis. Folia Historica” 1992, z. 44, s. $13-27$.

Chuvin P., Ostatni poganie. Zanik wierzeń pogańskich $w$ cesarstwie rzymskim od panowania Konstantyna do Justyniana, przekł. J. Stankiewicz-Prązyńska, Warszawa 2008.

Conrad L.I., Zeno, the Epileptic Emperor: Historiography and Polemics as Sources of Realia, „Byzantine and Modern Greek Studies” 2000, vol. XXIV, s. 61-81.

Crawford P., Roman Emperor Zeno: The Perils of Power Politics in Fifth-century Constantinople, Yorkshire-Philadelphia 2019.

Demougeot E., La formation de l'Europe et les invasions barbares, t. II (De l'avènement de Dioclétien [284] à l'occupation germanique de l'Empire romain d'Occident (début du VI e siècle]), Paris 1979.

Downey G., A History of Antioch in Syria from Seleucus to the Arab Conquest, Princeton-New Jersey 1961.

Elton H., Illus and the Imperial Aristocracy under Zeno, „Byzantion” 2000, vol. LXX, s. 393-407.

Ensslin W., Leontius, [w:] Paulys Realencyclopädie der classischen Altertumswissennschaft, Suppl. Bd. VIII, Stuttgart 1948, k. 939-941.

Ensslin W., Marcianus 35, [w:] Paulys Realencyclopädie der classischen Altertumswissennschaft, Bd. XIV, 2, Stuttgart 1956, kol. 1519.

Feissel D., Cesarz i administracja cesarska, [w:] Świat Bizancjum, t. I (Cesarstwo wschodniorzymskie 330-641), red. C. Morrisson, przekł. A. Graboń, Kraków 2007, s. 97-132.

Feld K., Barbarische Bürger. Die Isaurier und das Römische Reich, Berlin 2005.

Feld K., Pamprepius. Philosoph und Politiker oder Magier und Aufrührer?, [w:] Gelehrte in der Antike. Alexander Demandt zum 65. Geburtstag, hrsg. A. Goltz, A. Luther, H. Schlange-Schöningen, Köln-Wiemar-Wien 2002, s. 261-280.

Frend W.H.C., The Rise of Monophysite Movement. Chapters in the History of the Church in the Fifth and Sixth Centuries, Cambridge 1972.

Ginter K., Wizerunek władców bizantyńskich w Historii kościelnej Ewagriusza Scholastyka, Łódź 2018.

Glušanin E.P., Voennaja znat' rannej Vizantii, Barnaul 1991.

Gottwald J., Die Kirche und das Schloss Paperon in Kilikisch-Armenien, „Byzantinische Zeitschrift" 1936, Bd. XXXVI, s. 86-100.

Heather P.J., Goths and Romans 332-489, Oxford 1991.

Hild F., Hellenkemper H., Kilikien und Isaurien, Teil I, Wien 1990 (Tabula Imperii Byzantini 5.1). 
Janiszewski P., Historiografia późnego antyku (koniec III-połowa VII w.), [w:] Vademecum historyka starożytnej Grecji i Rzymu, t. III (Źródłoznawstwo czasów późnego antyku), red. E. Wipszycka, Warszawa 1999, s. 7-220.

Kiel-Freytag A., Betrachtungen zur Usurpation des Illus und des Leontius (484 488 n. Chr., „Zeitschrift fur Papyrologie und Epigraphik” 2010, Bd. CLXXIV, s. 291-301.

Kokoszko M., Descriptions of Personal Appearance in John Malalas' Chronicle, Łódź 1998.

Kosiński R., Kilka uwag o Henotikonie i domniemanym zwrocie $w$ polityce religijnej cesarza Zenona, [w:] Społeczeństwo i religia $w$ świecie antycznym. Materiały $z$ ogólnopolskiej konferencji naukowej (Toruń, 20-22 września 2007 r.), red. S. Olszaniec, P. Wojciechowski, Toruń 2010, s. 433-451.

Kosiński R., The Emperor Zeno. Religion and Politics, Cracow 2010.

Kulakovkij J., Istorija Vizantii, t. I, London 1973.

Laniado A., Some Problems in the Sources for the Reign of the Emperor Zeno, „Byzantine and Modern Greek Studies” 1991, vol. XV, s. 147-173.

Lenski N., Assimilation and Revolt in the Territory of Isauria, from $1^{\text {st }}$ Century $B C$ to the $6^{\text {th }}$ Century AD, "Journal of the Economic and Social History of the Orient” 1999, vol. XLII, s. 413-465.

Leszka M.J., Bunt Marcjana w Konstantynopolu (479), [w:] Z badań nad wczesnobizantyńskim Konstantynopolem, red. M.J. Leszka, K. Marinow, A. Kompa, Łódź 2011 (= „Acta Universitatis Lodziensis. Folia Historica” 2011, z. 87), s. $215-225$.

Leszka M.J., Empress-Widow Verina's Political Activity during the Reign of Emperor Zeno, [w:] Mélanges d'histoire byzantine offerts à Oktawiusz Jurewicz à l'occasion de son soixante-dixième Anniversaire, ed. W. Ceran, Łódź 1998, s. $128-136$.

Leszka M.J., Illus Izauryjczyk wobec uzurpacji Bazyliskosa, „Acta Universitais Lodziensis. Folia Historica” 2005, z. 80, s. 45-53.

Leszka M.J., John the Scythian - a Slayer of usurpers and the Isaurians, „Studia Ceranea" 2020, vol. X, s. 383-397.

Leszka M.J., Kilka uwag na temat losów Illusa Izauryjczyka $w$ latach 479-484, „Meander” 2007, R. XL, z. 1-2, s. 99-107.

Leszka M.J., On Leontius' Origin and Career up until the Year 481/482, „Piotrkowskie Zeszyty Historyczne" 2020, t. XXI, z. 3, s. 9-18.

Leszka M.J., The Career of Flavius Appalius Illus Trocundes, „Byzantinoslavica” 2013, t. LXXI, s. 47-58.

Leszka M.J., Uzurpacje $w$ cesarstwie bizantyńskim $w$ okresie od IV do połowy IX wieku, Łódź 1999.

Leszka M.J., Watki religijne $w$ propagandzie wczesnobizantyńskich uzurpatorów. Przypadek Illusa i Leoncjusza (484), „Christianitas antiqua” 2014, nr 6, s. $188-193$.

Martindale J.R., The Prosopography of the Later Roman Empire, vol. II (A.D. 395-527), Cambridge 1980. 
McCail R.C., P. Gr. Vindob. 29788C: hexameter encomium on an un-named emperor, „Journal of Hellenic Studies” 1978, vol. XCVIII, s. 38-63.

Pitsakis K.G., Sainteté et empire. A propos de la sainteté impériale: formes de sainteté „d'office” et de sainteté collective dans l'Empire d'Orient, „Bizantinistica” 2002, t. III, s. 155-227.

Prostko-Prostyński J., Basiliskos: Ein in Rom anerkannter Usurpator, „Zeitschrift für Papyrologie und Epigraphik" 2000, Bd. CXXXIII, s. 259-263.

Salamon M., Basiliscus cum Romanis suis, [w:] Studia Moesiaca, red. L. Mrozewicz, K. Ilski, Poznań 1994, s. 179-196.

Salamon M., Pamprepiusz z Panopolis - pisarz, profesor, polityk, obrońca pogaństwa $w$ Cesarstwie Wschodnim, [w:] Studia classica et byzantina. Alexandro Krawczuk oblata, red. M. Salamon, Z.J. Kapera, Kraków 1996, s. 163-195.

Salamon M., Problem upadku Cesarstwa Rzymskiego w greckiej historiografii powszechnej początków VI wieku (Zosimos i Eustacjusz z Epifanii), „Historia i Współczesność” 1978, t. III, s. 115-129 (= Problemy schyłku świata antycznego, red. A. Kunisz, Katowice 1978, s. 115-127).

Tinnefeld F., Kategorien der Kaiserkritik in der byzantinischen Historiographie von Prokop bis Nicetas Choniates, Münich 1971.

Trombley F.R., Hellenic Religion and Christianization c. 370-529, vol. I, LeidenNew York-Köln 1993.

Twardowska K., Cesarzowe bizantyńskie 2 poł. Vw. Kobiety i władza, Kraków 2009.

Twardowska K., Rzymski Wschód w latach 395-518, [w:] Świat rzymski w V wieku, red. R. Kosiński, K. Twardowska, Kraków 2010, s. 79-128.

Vallejo-Girvés M., Empress Verina among the Pagans, [w:] Pagans and Christians in the Late Roman Empire. New Evidence, New Approaches (4 $4^{\text {th }}-8^{\text {th }}$ centuries), eds M. Sághy, E.M. Schoolman, Budapest 2017, s. 43-58.

Whitby M., Evagrius on Patriarchs and Emperors, [w:] The Propaganda of Power. The Role of Panegyric in Late Antiquity, ed. M. Whitby, Leiden-Boston-Köln 1998, s. 321-344.

Wilczyński M., Germanie w służbie zachodniorzymskiej w Vw. n.e., Oświęcim 2018. Wolfram H., Historia Gotów, przeł. R. Darda-Staab i in., Warszawa-Gdańsk 2003.

NOTKA O AUTORZE:

Prof. dr hab. Mirosław Leszka - zatrudniony w Katedrze Historii Bizancjum Uniwersytetu Łódzkiego na stanowisku profesora.

Zainteresowania naukowe: dzieje Bizancjum i średniowiecznej Bułgarii, w szczególności: uzurpacje w okresie wczesno-i średniobizantyńskim, arystokracja wojskowa w drugiej połowie V w., cesarzowe w okresie wczesno- i średniobizantyńskim, Konstantynopol w okresie wczesno- i średniobizantyńskim, stosunki bizantyńsko-bułgarskie VII-XII w., dzieje państwowości bułgarskiej VII-XI w.

miroslaw.leszka@uni.lodz.pl 